\title{
AN INVESTIGATION OF HERDING BEHAVIOR IN TURKISH MUTUAL FUND INDUSTRY
}

\section{TÜRKIYYE’ DE YATIRIM FONU ENDÜSTRİSINDE SÜRÜ DAVRANIŞININ İNCELENMESI}

\author{
Pinar EVRİM MANDACI* \\ Zeliha CAN ERGÜN** \\ F. Dilvin TAŞKIN YEŞILLOVA ${ }^{* *}$
}

\begin{abstract}
This paper investigates the herding behavior of mutual fund managers in Turkey by using monthly data for the period from March 2014 to April 2017. We collect data from the monthly reports of 18 common stock mutual funds. First, we use the herding measure (Hi,t) that was developed by Lakanishok, Shleifer and Vishny (1992) to point out the stock picking herding, and then we apply the buying and selling side herding measures of Wermers (1999) to see the direction of this stock picking herding. Additionally, we apply an alternative measure of herding introduced by Oehler (1998), to determine the overall extent of mutual fund herding (market-wide herding). While our results on stock picking herding indicate the existence of any herding, the results on market-wide herding indicates the presence of it.

Keywords: Behavioral Finance, Herding Behavior, Mutual Funds

Jel Classification: G4, G14, G23

Öz

Bu çalışmada Türkiyedeki fon yöneticilerinin aylık veri kullanılarak Mart 2014-Nisan 2017 aralığında sürü davranışları araştırılmıştır. Veriler 18 hisse senedi yatırım fonunun aylık raporlarından elde edilmiştir. Öncelikle Lakonishok, Shleifer ve Vishny (1992) tarafından geliştirilen sürü davranışı göstergesi (Hi,t) kullanarak

* Prof. Dr., Dokuz Eylul University, Faculty of Business, Department of Business Administration, Kaynaklar Campus, Buca-IZMì, pinar.evrim@deu.edu.tr.

** Res. Asst., Adnan Menderes University, Faculty of Business, Department of International Trade and Business, Söke-AYDIN, zeliha.can@adu.edu.tr.

*** Assoc. Prof. Dr., Yasar University, Faculty of Economics and Administrative Sciences, Department of Business Administration, Bornova-İZMİR, dilvin.taskin@yasar.edu.tr.
\end{abstract}


hisse seçimi sürü davranışının varlığı, ardından hisse seçiminin yönünü görmek için Wermers (1999) tarafından ortaya konan alma ve satma yönlü sürü davranışı göstergeleri incelenmiştir. Ayrıca, Oehler’in (1998) sunduğu yatırım fonları arasındaki genel sürü davranışı (piyasa çapında sürü davranışı) varlığı incelenmiştir. Sonuçlar hisse seçimi açısından anlamlı bir sürü davranışına işaret etmezken, piyasa çapında sürü davranışının var olduğunu göstermektedir.

Anahtar Kelimeler: Davranışsal Finans, Sürü Davranışı, Yatırım Fonları

Jel Sınıflandırması: G4, G14, G23

\section{Introduction}

Herding is the tendency for a group of investors to buy or sell the same stocks simultaneously (Hung et al, 2010). Herding is also defined as a change in one person's behavior because of real or imagined pressure from a person or a group (Aronson, 1992). Various theoretical models try to explain the rationale behind these simultaneous transactions. These models explain the herding behavior in terms of two aspects, information driven herding and behavior driven herding (Bickhchandani and Sharma, 2001).

Information driven herding models state that herding arises because of the similar educational backgrounds of the investors. Investors use similar information and act by undertaking similar investment strategies (Heich, 2013). If information-driven motives trigger the herding behavior, these transactions are likely to stabilize stock prices. Behavior driven models, on the other hand, is the tendency of the investors to follow others. With this form of motive, the transactions will destabilize the market. Since psychological factors lead to alterations in optimal decision-making, it is possible to infer that most of the time models of herding are based on behavior driven models. These models are;

\section{Principal-Agent Models}

These models suggest that there are two types of agents, which are either smart or dumb. The compensation paid to these agents depends on the abilities of these agents to interpret the market. Smart agents receive informative private signals and dumb agents receive purely noisy signals (Oehler and Chao, 2000). This model assumes that the smart agents' signals are correlated because they reached to the same truth using similar information and knowledge (Scharfstein and Stein, 1990). Conversely, dumb agents have uncorrelated signals. Thus, in order to "look-smart" dumb agents imitate the acts of smart agents; thus, they will be considered as smart in the eyes of principals.

\section{Cascade Models}

Cascades take place when investors gather private information from prior trades made by better-informed investors and follow their transactions (Banerjee, 1992). Investors ignore their noisy 
signals and try to pick information from previous investors' transactions (Bickhchandani and et al, 1992). The cascades tend to destabilize the stock prices because investors believe that the fundamental value of a stock is wrong.

\section{Information Acquisition Models (Characteristic Herding)}

Institutions may be more interested in some of the stocks because of their specific characteristics such as liquidity or volatility (Falkenstein, 1990). These kinds of characteristics cause the investors to study the same sources of information studied by other investors or institutions. Some investors will be more likely to find information than others, that will cause them to be more profitable due to the moves of the late investors (Hirshleifer and et al, 1994). The late informed investors are more likely to enter into the same transaction as they realize the increased profits of the prior investor, which in turn will increase the cascade.

Although a vast amount of literature exists on the institutional herding, the best of authors' knowledge no paper analyze the herding behavior among mutual fund managers in Turkey. In order to fill this gap this paper focus on the mutual fund companies that invested more than fifty percent of its assets to equities markets in Turkey for the period between March 2014 and April 2017. The paper is organized as follows in Section 2 we will provide the summary of the existing studies, Section 3 will provide empirical analysis including the information on data, methodology and the results. Section 4 concludes the paper.

\section{Literature Review}

The herd behavior literature is mainly intended to analyze the existence of herd behavior on stock markets by using different measurement types of herd behavior. There are many models that were developed to measure herd behavior. However; the most common measurement types are; Lakonishok, Shleifer and Vishny (LSV) Measurement which was developed by Lakonishok, Shleifer and Vishny (1992); Cross Sectional Volatility of the Stocks which was developed by Christie and Huang (1995) and Chang, Cheng and Khorana (2000); and Beta Herding which was developed by Hwang and Salmon (2004). Within this scope, researchers used various measurement types of herd behavior in order to test the existence of herd behavior in different country's stock markets. Choe, Kho and Stulz(1998) analyzed herd behavior in Korean stock market by implementing LSV measurement in the period of 1996 to 1997 which also include the economic crisis period. As a result of their analyses they found significant evidence of herd behavior in the Korean stock market. Similarly, Hsieh (2013) used LSV measurement to examine the herd behavior of individual and institutional investors in the Taiwan stock market, and it is detected that herd behavior is present for both investors.

Moreover, Caporale, Economou and Philippas (2008) used cross sectional dispersion of stock returns to detect herd behavior on Athens Stock Exchange (ASE) between the year 1998 and 2007, and they also found significant evidence of herd behavior. Likewise, Ouardo, El Bouri and Bernard (2013) examined the existence of herd behavior for the European financial markets between 1998 
and 2010 by focusing on each sector; and they accepted Stoxx600 index as a representative of the Euro-zone countries. As a result, except the consumer goods sector, they found significant evidence of herd behavior in that index. Lastly, Gavriilidis, Kallinterakis and Micciullo (2006) used beta herding method to examine herd behavior in Argentina financial crisis between 2000 and 2006. In consequence of their analyses, they found significant evidence of herd behavior for both during and after crisis periods.

Except those studies that were conducted in various markets, there are also some studies in Turkey examining the existence of herd behavior in Borsa Istanbul (BIST). Some of those studies reached significant evidence of herd behavior in BIST. Altay (2008) examined herd behavior in BIST by using both cross sectional dispersion of stock returns and beta herding methods between 1997 and 2008. BIST-All shares index was used for the indication of market portfolio and it is found that there is evidence of herd behavior in BIST during these periods. Moreover, Kapusuzoğlu (2011) examined herd behavior in BIST-100 index by using cross sectional dispersion of stock returns for the period 2000 to 2010, and the same results were obtained with Altay (2008). Similarly, Kayalidere (2012) analyzed herd behavior between 1997 and 2012, and he divided the period into two sub periods as 1997-2004 and 2005-2012. As a result of analyses, it is found that there is an evidence of herd behavior in the first sub period, but its impact decreases in the second sub period. On the other hand, some other studies that were conducted in Turkey could not reach any significant evidence of herd behavior in BIST. One of those studies is conducted by Çoban (2009) between 1997 and 2008. Adjusted daily closing prices of 257 stocks were used and he did not find any significant evidence of herd behavior. Likewise, Doğukanlı and Ergün (2011) used monthly closing prices for the period 2000 to 2010 and they also did not find any significant evidence of herd behavior in BIST. Although the mentioned studies were conducted in the same market; as mentioned previously, they could not reach consistent results with each other. It may be resulted from the different types of herd behavior measurements and different usage of data sets.

Apart from these studies, there are also studies determining the effect of herd behavior for institutional investors. One of these studies was conducted initially by Lakonishok, Shleifer and Vishny (1992) and they analyzed the herd behavior of institutional money managers. Their data is composed of quarterly portfolio holdings of 769 all-equity pension funds between 1985 and 1989. As a result, they found evidence of herd behavior by fund managers only in small stocks. Therefore, they did not find evidence about institutional investors destabilize individual stock prices. Concurrently, their measurement method of herd behavior (shortly LSV measurement) which was implemented in this study was inspired many following studies. Another important study is conducted by Grinblatt, Titman and Wermers (1995). Similarly, they examined the trading patterns of fund managers by using quarterly holdings of 155 mutual funds between 1975 and 1984. They used LSV measurement of herding and they found that managers tend to decide to buy stocks based on their past returns, and they show herd behavior by buying and selling the same stocks at the same time. Although they find a significant evidence of herd behavior; it is not very large. Therefore, it could be concluded that both the studies of Lakonishok, Shleifer and Vishny (1992) and Grinblatt, Titman and Wermers (1995) found little evidence of herd behavior for fund managers. Bikhchandani and Sharma (2001) evaluated these understated herd behavior results by two reasons. First, they stated that the types of 
mutual funds may be too heterogeneous; and second, the trading volumes may be too low for observing any significant herd behavior. Similar to those studies, Wermers (1999) analyzed the herd behavior of mutual fund managers and the effect of herd behavior on stock prices during the period 1975 to 1994. They used LSV measurement to detect herd behavior and as a result of the analyses they found low level of herd behavior in trading activity of the mutual funds as former studies.

In addition, Walter and Weber (2006) examined the effects of herd behavior on the trading activity of German mutual funds and its impact on stock prices between 1998 and 2002. As in other studies, they used LSV measurement and they detected the evidence of herd behavior. They found that during the boom periods "buy side" herd behavior is the highest, during the crash periods "sell side" herd behavior is the highest. In contrast to previous studies, they did not find significant differences between herd behavior of small stocks and big stocks. They also concluded that herd behavior of mutual fund managers do not affect the stock prices. Herd behavior of German mutual fund managers was also analyzed by Oehler and Wendt (2009) between 2000 and 2005. By using LSV measurement of herd behavior; they found that when there are market-wide cash inflows or outflows, there is significant herd behavior of mutual fund managers.

Mutual fund managers' herd behavior is also examined in other various markets. Hung, Lu and Lee (2010) examined the herd behavior of mutual fund managers in Taiwan stock market, and they found that there is a tendency of herd behavior in that market. Patro and Kanagaraj (2012) analyzed the trading activity of Indian mutual funds and examined whether Indian mutual fund managers are engaged in herd behavior. As a result, they found strong evidence of herd behavior. In addition, they found that the Indian mutual funds seem to herd more in large stocks compared to smaller stocks. Moreover, the Indian mutual funds seem to herd more than developed markets. Different from other studies Gavriilidis, Kallinterakis and Ferreira (2013) examined whether fund managers herd behavior is intentional or not. They also investigated whether the institutional herd behavior is related to the specific conditions of each industry or whether it is related with the market as a whole. They used quarterly holdings of Spanish mutual funds between 1995 and 2008. As a result of their analyses, they found that fund managers herd at the overall market level. They also found that their herd behavior is intentional, because that kind of behavior of fund managers generally motivated by informational and career-related reasons.

To the best of authors' knowledge, any study analyzed the herd behavior tendency of mutual fund managers in Turkey. Therefore, this paper contributes to the literature by examining the effect of herd behavior on mutual funds in Turkey.

\section{Empirical Analysis}

\section{I. Data and Data Process}

We collect data from the web page of Public Disclosure Platform of Turkey. We only include common stock mutual funds investing more than fifty percent of their assets into common stocks. We collect the proportions of each company's stock in each sample fund for each month for the period 
from March 2014 to April 2017 (36 months-3 years). The buying and selling activities of each fund for each common stock is determined by taking the differences of the monthly proportions.

Currently, there are 32 stock weighed mutual funds in Turkey. We omit nine of them since their data is not available beginning from March 2014 in other words they are very new. In addition, we omit five of them since they have missing data. As a result, our data consist 18 stock weighed mutual funds representing almost the overall market. These 18 funds invested 206 common stocks traded in BIST.

As a result, our data sample contains 648 portfolio distribution reports (36 monthly reports of 18 Mutual funds). From each report, we hand collect the proportions of shares held of every company in the stock weighted mutual fund's portfolio.

\subsection{Methodology}

We employ the herding measure that was developed by Lakanishok, Shleifer and Vishny (1992). According to them herding is the tendency of investors to aggregate on the same side of the market relative to what could be expected if they traded separately. Their model considers the net changes in stockholdings.

Therefore, in this study we determine net changes in stockholding from each of the 37 reports for every fund $k$ at reporting time $t$. For each firm $i$ and every reporting date $t$ we define the number of net buyers, $B_{i, t}$, and of net sellers, $S_{i, t}$ i.e. the number of mutual funds that increase or decrease their investment in those firms as

$$
\begin{aligned}
& B_{i, t}=\sum_{k} b_{i, k, t} \\
& S_{i, t}=\sum_{k} s_{i, k, t}
\end{aligned}
$$

In order to determine the overall extent of the herding behavior in the complete data set, we use the herding measure of Lakonishok, Shleifer, and Vishny (1992) (1992) and define as $H_{i, t}$ for each share $i$ at time $\mathrm{t}$ as;

$$
H_{i, t}=\left|\frac{B_{i, t}}{B_{i, t}+S_{i, t}}-p_{t}\right|-A F_{i, t}
$$

where

$$
p_{t}=\frac{\sum_{i} B_{i, t}}{\sum_{i} B_{i, t}+S_{i, t}}
$$

And 


$$
A F_{i, t}=E\left[\left|\frac{B_{i, t}}{B_{i, t}+S_{i, t}}-p_{t}\right|\right]=\operatorname{Bin}\left(\frac{B_{i, t}}{B_{i, t}-S_{i, t}}, p_{t}\right)
$$

The term $\frac{\bar{B}_{i, t}}{\bar{B}_{i, t}+s_{i, t}}$ is the buying ratio for stock i at time t. $p_{t}$ is the average of buying ratio for all stocks at time t. It measures the proportion of all buying activities relative to all trading activities (buy and sell) of the mutual funds between two reporting dates and reflects the general tendency to increase the equity holdings, i.e. to buy. Thus, $p_{t}$ can be interpreted as the expected proportion of funds that buy shares in period $t$.

The adiustment factor $A F_{i, t}$ may be interpreted as the expected value of the term $\left|\frac{\bar{B}_{i, t}}{\bar{B}_{i, t}+s_{i, t}}-p_{t}\right|$ $\left|\frac{\bar{B}_{i, t}}{\bar{B}_{i, t}+s_{i, t}}-p_{t}\right|$. It is subtracted to consider for the possibility of observing more variation in the buying ratio of stocks with only a few trades and controls for the probability that the observed buying behavior is the result of a random process. The trading decision concerning a particular share is modeled as a random variable that is Bernoulli-distributed with a value of 1 in the case of a buying event and zero otherwise. For each share $i$ we receive $\mathrm{B}_{\mathrm{i}, \mathrm{t}}$ buying events. When drawing the $\mathrm{B}_{\mathrm{i}, \mathrm{t}}+\mathrm{S}_{\mathrm{i}, \mathrm{t}}$ active funds with an overall buying probability distribution $\mathrm{p}_{\mathrm{t}}$ the expected value follows a binominal distribution. The values of zero. $H_{i, t}$ range from -1 to +1 with no herding being represented by a value of zero (Oehler and Wendt, 2009). Under the null hypothesis of no herding the mean herding measure is expected to be insignificantly different from zero.

The herding measure does not consider the direction of the trades. Therefore, by following Wermers (1999), we determine buy herding and sell herding to separate stocks bought and sold by herds. The herding measure of stock is categorized as buy (sell) side herding when the buy ratio on stock i is higher (lower) than the buy ratio on the whole market.

$$
\begin{aligned}
& B H_{i, t}=H_{i, t} \text { if } \frac{B_{i, t}}{B_{i, t}+S_{i, t}}>p_{t} \\
& S H_{i, t}=H_{i, t} \text { if } \frac{B_{i, t}}{B_{i, t}+S_{i, t}}<p_{t}
\end{aligned}
$$

By accounting for the general tendency of funds to buy shares, the influence of market-wide herding is eliminated. This means that only stock-picking herding, i.e. similar buying and selling patterns beyond the market trend, is analyzed. However, this procedure ignores the fact that market-wide net cash inflows or outflows should not lead to similar decisions if we assume active fund management. Thus, market-wide herding is inconsistent with active portfolio management.

Therefore, following Oehler (1998), we use the following measure to determine the overall extent of mutual fund herding.

$$
H F_{i, t}=\left|\frac{B_{i, t}-S_{i, t}}{B_{i, t}+S_{i, t}}\right|
$$

Similar to the $\mathrm{H}_{\mathrm{i}, \mathrm{t}}$ variable we defined above, $H F_{i, t}$ uses the number of net buyers and net sellers. 


\subsection{Empirical Results}

Table 1 presents the results of the whole sample with regard to stock-picking herding using the herding measure $\left(\mathrm{H}_{\mathrm{i}, \mathrm{t}}\right)$ of Lakonishok, Shleifer, and Vishny (1992) at a monthly frequency. Based on the mean of $\mathrm{H}_{\mathrm{i}, \mathrm{t}}$ no economically significant herding can be identified in any month. The herding measure is at most 4\% on May 2014, October 2015 and December 2015. We observe any herding during July 2014 and February 2015. For the other months, the value of herding measures is very low. The median values of the herding measures are also very low.

Table I: Stock Peaking Herding Determined by Applying Hi,t

\begin{tabular}{|c|c|c|c|c|c|c|c|c|c|}
\hline & $2014 / 04$ & $2014 / 05$ & $2014 / 06$ & $2014 / 07$ & $2014 / 08$ & $2014 / 09$ & $2014 / 10$ & $2014 / 11$ & $2014 / 12$ \\
\hline Mean & 0,02 & 0,04 & 0,01 & 0,00 & 0,02 & 0,02 & 0,03 & 0,01 & 0,03 \\
\hline Median & $-0,02$ & 0,05 & $-0,03$ & $-0,02$ & $-0,01$ & $-0,01$ & 0,00 & $-0,02$ & $-0,01$ \\
\hline \multirow[t]{2}{*}{ StDev } & 0,14 & 0,13 & 0,14 & 0,14 & 0,14 & 0,15 & 0,14 & 0,13 & 0,13 \\
\hline & $2015 / 01$ & $2015 / 02$ & $2015 / 03$ & $2015 / 04$ & $2015 / 05$ & $2015 / 06$ & $2015 / 07$ & $2015 / 08$ & $2015 / 09$ \\
\hline Mean & 0,01 & \begin{tabular}{|l|}
0,00 \\
\end{tabular} & 0,02 & 0,01 & 0,03 & 0,02 & 0,02 & $-0,01$ & 0,02 \\
\hline Median & $-0,03$ & 0,00 & $-0,02$ & $-0,03$ & 0,02 & 0,01 & $-0,01$ & $-0,01$ & $-0,02$ \\
\hline \multirow[t]{2}{*}{ StDev } & 0,13 & 0,12 & 0,14 & 0,13 & 0,13 & 0,14 & 0,15 & 0,14 & 0,13 \\
\hline & $2015 / 10$ & $2015 / 11$ & $2015 / 12$ & \begin{tabular}{|l|}
$2016 / 01$ \\
\end{tabular} & $2016 / 02$ & $2016 / 03$ & $2016 / 04$ & $2016 / 05$ & $2016 / 06$ \\
\hline Mean & 0,04 & 0,02 & 0,04 & \begin{tabular}{|l|}
0,02 \\
\end{tabular} & 0,03 & 0,03 & 0,02 & 0,03 & 0,03 \\
\hline Median & $-0,01$ & $-0,01$ & 0,06 & $-0,01$ & 0,00 & 0,01 & 0,00 & $-0,02$ & 0,02 \\
\hline \multirow[t]{2}{*}{ StDev } & 0,14 & 0,13 & 0,16 & 0,14 & 0,13 & 0,14 & 0,14 & 0,13 & 0,12 \\
\hline & $2016 / 07$ & $2016 / 08$ & $2016 / 09$ & $2016 / 10$ & $2016 / 11$ & $2016 / 12$ & $2017 / 01$ & $2017 / 02$ & $2017 / 03$ \\
\hline Mean & 0,03 & 0,01 & 0,01 & 0,03 & 0,02 & 0,02 & 0,03 & 0,02 & 0,03 \\
\hline Median & 0,03 & $-0,02$ & $-0,01$ & 0,02 & 0,00 & $-0,01$ & 0,03 & 0,01 & $-0,04$ \\
\hline StDev & 0,13 & 0,13 & 0,13 & 0,13 & 0,13 & 0,12 & 0,12 & 0,13 & 0,14 \\
\hline
\end{tabular}

Table 2 depicts the buy and sell side herding measure (BHM and SHM) of Wermers (1999) at a monthly frequency. We observe buying side herding for year 2014 on August, October and December; for year 2016 on January, February, May, June and November, and for 2017 only on April. On the other side, there exists selling side herding on April 2014 and October 2015. However, these values are not statistically significant.

Table 2: Stock Picking Herding Determined by Applying BHM and SHM

\begin{tabular}{|c|c|c|c|c|c|c|c|c|c|c|c|c|}
\hline & \multicolumn{2}{|c|}{$2014 / 04$} & \multicolumn{2}{|c|}{$2014 / 05$} & \multicolumn{2}{|c|}{ 2014/06 } & \multicolumn{2}{|c|}{ 2014/07 } & \multicolumn{2}{|c|}{$2014 / 08$} & \multicolumn{2}{|c|}{$2014 / 09$} \\
\hline & BHM & SHM & BHM & SHM & BHM & SHM & BHM & SHM & BHM & SHM & BHM & SHM \\
\hline Mean & $-0,03$ & 0,08 & 0,03 & 0,06 & $-0,01$ & 0,03 & 0,00 & 0,01 & 0,07 & $-0,02$ & 0,00 & 0,04 \\
\hline Median & $-0,07$ & 0,10 & $-0,04$ & 0,05 & $-0,07$ & 0,02 & $-0,06$ & 0,07 & 0,10 & $-0,07$ & 0,01 & $-0,01$ \\
\hline \multirow[t]{3}{*}{ StDev } & 0,09 & 0,16 & 0,13 & 0,13 & 0,12 & 0,17 & 0,12 & 0,16 & 0,17 & 0,09 & 0,17 & 0,10 \\
\hline & \multicolumn{2}{|c|}{$2014 / 10$} & \multicolumn{2}{|c|}{ 2014/11 } & \multicolumn{2}{|c|}{$2014 / 12$} & \multicolumn{2}{|c|}{$2015 / 01$} & \multicolumn{2}{|c|}{$2015 / 02$} & \multicolumn{2}{|c|}{$2015 / 03$} \\
\hline & BHM & SHM & BHM & SHM & BHM & SHM & BHM & SHM & BHM & SHM & BHM & SHM \\
\hline Mean & 0,06 & 0,00 & 0,00 & 0,01 & 0,05 & 0,01 & 0,02 & $-0,01$ & 0,04 & $-0,03$ & $-0,01$ & 0,04 \\
\hline Median & 0,00 & 0,00 & $-0,06$ & 0,08 & 0,07 & $-0,06$ & $-0,03$ & 0,03 & 0,09 & $-0,06$ & $-0,07$ & 0,02 \\
\hline
\end{tabular}




\begin{tabular}{|c|c|c|c|c|c|c|c|c|c|c|c|c|}
\hline StDev & 0,12 & 0,16 & 0,11 & 0,15 & 0,15 & 0,12 & 0,12 & 0,14 & 0,14 & 0,09 & 0,11 & 0,16 \\
\hline & \multicolumn{2}{|c|}{$2015 / 04$} & \multicolumn{2}{|c|}{ 2015/05 } & \multicolumn{2}{|c|}{$2015 / 06$} & \multicolumn{2}{|c|}{ 2015/07 } & \multicolumn{2}{|c|}{ 2015/08 } & \multicolumn{2}{|c|}{ 2015/09 } \\
\hline & BHM & SHM & BHM & SHM & BHM & SHM & BHM & SHM & BHM & SHM & BHM & SHM \\
\hline Mean & 0,01 & 0,00 & 0,02 & 0,04 & 0,02 & 0,01 & 0,03 & 0,01 & 0,03 & $-0,04$ & 0,03 & 0,01 \\
\hline Median & $-0,03$ & 0,03 & $-0,02$ & 0,02 & 0,01 & $-0,05$ & $-0,01$ & 0,01 & $-0,01$ & 0,01 & 0,03 & $-0,03$ \\
\hline \multirow[t]{3}{*}{ StDev } & 0,12 & 0,14 & 0,11 & 0,15 & 0,16 & 0,11 & 0,11 & 0,17 & 0,11 & 0,15 & 0,16 & 0,11 \\
\hline & \multicolumn{2}{|c|}{$2015 / 10$} & \multicolumn{2}{|c|}{$2015 / 11$} & \multicolumn{2}{|c|}{ 2015/12 } & \multicolumn{2}{|c|}{ 2016/01 } & \multicolumn{2}{|c|}{$2016 / 02$} & \multicolumn{2}{|c|}{ 2016/03 } \\
\hline & BHM & SHM & BHM & SHM & BHM & SHM & BHM & SHM & BHM & SHM & BHM & SHM \\
\hline Mean & 0,00 & 0,07 & 0,03 & 0,01 & 0,11 & \begin{tabular}{|l|}
$-0,02$ \\
\end{tabular} & 0,06 & $-0,02$ & 0,02 & 0,04 & 0,03 & 0,04 \\
\hline Median & $-0,05$ & 0,06 & $-0,01$ & 0,01 & 0,13 & $-0,09$ & 0,07 & $-0,06$ & $-0,04$ & 0,05 & $-0,01$ & 0,01 \\
\hline \multirow[t]{3}{*}{ StDev } & 0,11 & 0,15 & 0,11 & 0,14 & 0,17 & 0,13 & 0,16 & 0,09 & 0,12 & 0,15 & 0,10 & 0,16 \\
\hline & \multicolumn{2}{|c|}{ 2016/04 } & \multicolumn{2}{|c|}{$2016 / 05$} & \multicolumn{2}{|c|}{ 2016/06 } & \multicolumn{2}{|c|}{ 2016/07 } & \multicolumn{2}{|c|}{ 2016/08 } & \multicolumn{2}{|c|}{$2016 / 09$} \\
\hline & BHM & SHM & BHM & SHM & BHM & SHM & BHM & SHM & BHM & SHM & BHM & SHM \\
\hline Mean & 0,09 & $-0,03$ & 0,08 & $-0,02$ & 0,04 & 0,03 & 0,02 & 0,03 & 0,00 & 0,03 & 0,02 & 0,00 \\
\hline Median & 0,13 & $-0,08$ & 0,06 & $-0,05$ & 0,02 & $-0,02$ & 0,03 & $-0,03$ & \begin{tabular}{|l|}
$-0,05$ \\
\end{tabular} & 0,06 & $-0,01$ & 0,02 \\
\hline \multirow[t]{3}{*}{ StDev } & 0,16 & 0,10 & 0,15 & 0,09 & 0,14 & 0,10 & 0,14 & 0,11 & 0,10 & 0,15 & 0,12 & 0,13 \\
\hline & \multicolumn{2}{|c|}{$2016 / 10$} & \multicolumn{2}{|c|}{$2016 / 11$} & \multicolumn{2}{|c|}{$2016 / 12$} & \multicolumn{2}{|c|}{$2017 / 01$} & \multicolumn{2}{|c|}{$2017 / 02$} & \multicolumn{2}{|c|}{$2017 / 03$} \\
\hline & BHM & SHM & BHM & SHM & BHM & SHM & BHM & SHM & BHM & SHM & BHM & SHM \\
\hline Mean & 0,05 & 0,01 & 0,01 & 0,03 & 0,02 & 0,01 & 0,04 & 0,01 & 0,01 & 0,03 & 0,09 & $-0,03$ \\
\hline Median & 0,09 & $-0,05$ & $-0,06$ & 0,08 & 0,03 & $-0,02$ & 0,03 & $-0,03$ & 0,02 & $-0,02$ & 0,13 & $-0,09$ \\
\hline StDev & 0,14 & 0,12 & 0,11 & 0,14 & 0,13 & 0,11 & 0,14 & 0,11 & 0,15 & 0,10 & 0,15 & 0,10 \\
\hline
\end{tabular}

Table 3 presents the results of the whole sample with regard to benchmark herding by using $\mathrm{HF}_{\mathrm{i}, \mathrm{t}^{\circ}}$ In contrast to the results of stock picking herding measures, these results show the existence of herding. When we look at the median values, we can see that most of them equals to 1 or very closed to one indicating the existence of herding.

Table 3: Benchmark Herding Determined By Applying HFi,t (Whole Sample)

\begin{tabular}{|c|c|c|c|c|c|c|c|c|c|}
\hline & 2014/04 & $2014 / 05$ & $2014 / 06$ & $2014 / 07$ & 2014/08 & $2014 / 09$ & $2014 / 10$ & $2014 / 11$ & $2014 / 12$ \\
\hline Mean & 0,71 & 0,70 & 0,63 & 0,62 & 0,69 & 0,65 & 0,67 & 0,62 & 0,64 \\
\hline Median & 1,00 & 1,00 & 1,00 & 0,92 & 1,00 & 1,00 & 1,00 & 0,67 & 0,71 \\
\hline \multirow[t]{2}{*}{ StDev } & 0,37 & 0,38 & 0,41 & 0,42 & 0,38 & 0,40 & 0,40 & 0,40 & 0,38 \\
\hline & 2015/01 & $2015 / 02$ & $2015 / 03$ & $2015 / 04$ & $2015 / 05$ & $2015 / 06$ & $2015 / 07$ & $2015 / 08$ & $2015 / 09$ \\
\hline Mean & \begin{tabular}{|l|}
0,62 \\
\end{tabular} & 0,64 & \begin{tabular}{|l|}
0,65 \\
\end{tabular} & 0,60 & 0,67 & 0,62 & 0,64 & \begin{tabular}{|l|}
0,59 \\
\end{tabular} & 0,63 \\
\hline Median & 1,00 & 0,71 & 1,00 & 0,64 & 1,00 & 0,75 & 1,00 & 0,60 & 0,60 \\
\hline \multirow[t]{2}{*}{ StDev } & 0,42 & 0,38 & 0,40 & 0,41 & 0,38 & 0,41 & 0,41 & 0,41 & 0,38 \\
\hline & $2015 / 10$ & $2015 / 11$ & $2015 / 12$ & \begin{tabular}{|l|}
$2016 / 01$ \\
\end{tabular} & $2016 / 02$ & \begin{tabular}{|l|}
$2016 / 03$ \\
\end{tabular} & 2016/04 & \begin{tabular}{|l|}
$2016 / 05$ \\
\end{tabular} & $2016 / 06$ \\
\hline Mean & 0,67 & 0,62 & \begin{tabular}{|l|}
0,69 \\
\end{tabular} & 0,60 & 0,65 & 0,67 & 0,70 & 0,69 & 0,67 \\
\hline Median & 1,00 & 0,71 & 0,92 & 0,60 & 0,80 & 1,00 & 1,00 & 1,00 & 1,00 \\
\hline \multirow[t]{2}{*}{ StDev } & 0,37 & 0,40 & \begin{tabular}{|l|}
0,35 \\
\end{tabular} & 0,39 & 0,38 & 0,38 & 0,37 & 0,37 & 0,37 \\
\hline & \begin{tabular}{|l|}
$2016 / 07$ \\
\end{tabular} & $2016 / 08$ & \begin{tabular}{|l|}
$2016 / 09$ \\
\end{tabular} & $2016 / 10$ & 2016/11 & 2016/12 & $2017 / 01$ & $2017 / 02$ & $2017 / 03$ \\
\hline Mean & 0,65 & 0,63 & 0,60 & 0,67 & 0,66 & 0,67 & 0,66 & 0,65 & 0,66 \\
\hline Median & 0,80 & 1,00 & 0,60 & 1,00 & 1,00 & 1,00 & 1,00 & 1,00 & 1,00 \\
\hline StDev & 0,39 & 0,40 & 0,41 & 0,38 & 0,39 & 0,39 & 0,37 & 0,39 & 0,38 \\
\hline
\end{tabular}


Table 4 gives the averages of this herding measure for the period from April 2014 to March 2017. The mean values of Hi,t, BHM, and SHM are very low. Their median values are almost zero indicating the non-existence of herding. On the other hand, the mean and median values of the $\mathrm{HF}_{\mathrm{i}, \mathrm{t}}$ measure reports herding.

Table 4: Average Herding Measures (April 2014-March 2017)

\begin{tabular}{|l|c|c|c|c|}
\hline & Hi,t & BHM & SHM & H $_{\mathrm{Fi}}{ }^{\mathrm{t}}$ \\
\hline Mean & 0,02 & 0,03 & 0,01 & 0,65 \\
\hline Median & 0,00 & 0,01 & 0,00 & 0,89 \\
\hline StDev & 0,13 & 0,13 & 0,13 & 0,39 \\
\hline
\end{tabular}

\section{Conclusion}

Both the individual and institutional investors mimic each other's transactions causing herding and altering the prices in the markets. In order to understand the existence of herding in Turkish markets, this paper focus on the mutual funds' investments for the period between March 2014 and April 2017. We collect the proportions of each stock for each fund for each month and the buying and selling activities of each fund for each common stock is determined by taking the differences of the monthly proportions.

According to the results of the stock picking herding, no statistically significant herding is analyzed during the sample period. It is possible to conclude that characteristic herding does not exist between the fund managers. When the buying and selling side herding is analyzed, it is observed that in some months buying side herding exist and in two months selling side exist, but these values are not significant. Still, it is possible to interpret these findings, as the mutual fund managers are more likely to follow each other in their buying decisions. This finding could be explained with the principal agent model. The managers believe that their opponents have a profitable investment opportunity and they want to skim that opportunity too. On the other hand, limited selling side herding show that managers tend to believe in their intuitions rather than the other managers when they will close their positions. Finally, results for the market-wide herding shows an existence of herding.

Overall, the results indicate limited traces of stock picking herding among mutual fund managers but an evidence of market wide herding in Turkey. Our results are parallel to the findings of Oehler and Wendt (2009) that uses quarterly data. However, our results are opposite to the findings of Hsieh (2013) indicating the existence of stock picking herding by using daily data. The limitation of the paper might be the usage of monthly reports of the mutual fund companies. On the other hand, we could not reach data with more frequency such as daily or intraday for the mutual funds in Turkey. It is possible to find significant herding is timely provision of data is ensured. As a further study, it might be possible to examine the herding behavior for the retirement funds in Turkey which are in a growing pattern recently. 


\section{REFERENCES}

ALTAY, Erdinç. (2008). Sermaye Piyasasında Sürü Davranışı: IMKB’de Piyasa Yönünde Sürü Davranışının Analizi, BDDK Bankacılık ve Finansal Piyasalar, 2(1): 27-57.

ARONSON, Elliot. (1992). The Social Animal, The Random House Publishing Group, New York.

BANERJEE, Abhijit V. (1992). A Simple Model of Herd Behavior, Quarterly Journal of Economics, 107: 797-818.

BICKHCHANDANI, Sushil., HIRSCLEIFER, David. and WELCH, Ivo. (1992). A Theory of Fads, Fashion, Custom and Cultural Change as Informational Cascades, Journal of Political Economy, 100: 992-1026.

BIKHCHANDANI, Sushil., SHARMA, Sunil. (2001). Herd Behavior in Financial Markets, IMF Staff Papers. 47(3): 278-310.

CAPORALE, Guglielmo Maria, PHILIPPAS, Nikolaos and ECONOMOU, Fotini. (2008). Herding Behavior in Extreme Market Conditions: The Case of Athens Stock Exchange, Economics Bulletin, 7(17): 1-13.

CHANG, Eric.C., CHENG, Joseph.W. and KHORANA, Ajay. (2000). An Examination of Herd Behavior in Equity Markets: An International Perspective, Journal of Banking and Finance, 24(10): 1651-1679.

CHOE, Hyuk, KHO, Bong-Chan. and STULZ, René M. (1998). Do Foreign Investors Destabilize Stock Markets? The Korean Experience in 1997, Journal of Financial Economics, 54(2): 227-264.

CHRISTIE, William.G.and HUANG, Roger.D. (1995). Following the Pied Piper: Do Individual Returns Herd around the Market? Financial Analysts Journal, 51 (4): 31-37.

ÇOBAN, Ali.Türkay. (2009). “İMKB’de Sürü Davranışının Test Edilmesi”, Adana: Çukurova University Graduate School of Social Sciences, (Unpublished Master Dissertation).

DOĞUKANLI, Hatice and ERGÜN, Bahadır. (2011). İMKB’de Sürü Davranışı: Yatay Kesit Değişkenlik Temelinde Bir Araştırma, Çukurova Ünivsersitesi İşletme Fakültesi Dergisi, 12(2): 227-242.

FALKENSTEIN, Eric.G. (1996). Preferences for Stock Characteristics as Revealed by Mutual Fund Portfolio Holdings, Journal of Finance, 51(1): 111-135.

KALLINTERAKIS, Vasileios, GAVRIILIDIS, Konstantinos and MICCIULLO, Paula. (2006). The Argentine Crisis: A Case for Herd Behavior? Available at http://papers.ssrn.com/sol3/papers.cfm?abstract_ $\mathrm{id}=980685,(6.5 .2014)$.

GAVRIILIDIS, Konstantinos., KALLINTERAKIS, Vasileios and FERREIRA, Mario Pedro Leite. (2013). Institutional Industry Herding: Intentional or Spurious? Journal of International Financial Markets, Institutions and Money, 26 (2013): 192-214.

GRINBLATT, Mark., TITMAN, Sheridan. and WERMERS, Russ. (1995). Momentum Investment Strategies, Portfolio Performance and Herding: A Study of Mutual Fund Behavior, The American Economic Review, 85 (5): 1088 - 1105.

HIRSHLEIFER, David., SUBRAHMANYAM, Avanidhar and TITMAN, Sheridan. (1994). Security Analysis and Trading Patterns When Some Investors Receive Information before Others, Journal of Finance, 49 (5): 1665-1698.

HSIEH, Shu-Fan. (2013). Individual and Institutional Herding and the Impact on Stock Returns: Evidence from Taiwan Stock Market, International Review of Financial Analysis, 29 (2013): 175-188.

HUNG, Weifeng, LU, Chia-Chi and LEE, Cheng F. (2010). Mutual Fund Herding Its Impact on Stock Returns: Evidence from the Taiwan Stock Market, Pacific-Basin Finance Journal, 18 (2010): 477-493.

HWANG, Soosung., SALMON, Mark. (2004). Market Stress and Herding, Journal of Empirical Finance, 11(2004): 585-616.

KAPUSUZOĞLU, Ayhan. (2011). Herding in the Istanbul Stock Exchange (ISE): A Case of Behavioral Finance, African Journal of Business Management, 5(27): 11210-11218. 
KAYALIDERE, Koray. (2012). Hisse Senedi Piyasasında Sürü Davranışı: İMKB’de Ampirik Bir İnceleme, İsletme Araştırmaları Dergisi, 4(4): 77-94.

LAKONISHOK, Josef., SHLEIFER, Andrei and VISHNY, Robert W. (1992). The Impact of Institutional Trading on Stock Prices, Journal of Financial Economics, 32, 23-43.

OEHLER, Andreas. (1998). Do Mutual Funds Specializing in German Stocks Herd? Finanzmarkt und Portfolio Management 4, 452-465.

OEHLER, Andreas. and CHAO, George Goeth-Chi. (2000). Institutional Herding in Bond Markets, Discussion Papers 13.

OEHLER, Andreas. and WENDT, Stefan. (2009). Herding Behavior of Mutual Fund Managers in Germany. Available at SSRN: https://ssrn.com/abstract=1343470 (23.06.2017).

OUARDA, Moatemri, BOURI, Abdelfatteh el. and BERNARD, Olivero. (2013). Herding Behavior under Market Condition: Empirical Evidence on the European Financial Markets, International Journal of Economics and Financial Issues, 3(1): 214-228.

PATRO, Archana. and KANAGARAJ, Ayyalusamy. (2012). Exploring the Herding Behavior in Indian Mutual Fund Industry, Asian Journal of Finance and Accounting, 4(1): 189-204.

SCHARFSTEIN, David.S and STEIN, Jeremy C. (1990). Herd Behavior and Investment, American Economic Review, 80(3): 465-479.

WALTER, Andreas. and WEBER, Friedrich Moritz. (2006). Herding in the German Mutual Fund Industry, European Financial Management, 12 (3): 375-406.

WERMERS, Russ. (1999). Mutual Fund Herding and the Impact on Stock Prices, The Journal of Finance, 54 (2): 581-622. 